\title{
Atlas DP2d untuk Meningkatkan Hasil Belajar Biologi di Masa Pandemi Covid-19
}

\author{
Ni Luh Ratna Tirtawati ${ }^{*}$ \\ ${ }^{1}$ SMA Negeri 1 Semarapura, Klungkung, Indonesia
}

\section{ART I C L E IN F O}

Article history:

Received July 16, 2021

Revised July 25, 2021

Accepted October 20, 2021

Available online November 25, 2021

Kata Kunci:

Atlas DP2D, Hasil Belajar Biologi

Keywords:

Atlas and Biology Learning Outcomes

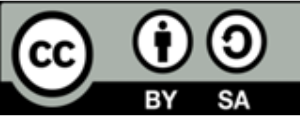

This is an open access article under the CC BY-SA license.

Copyright $(2021$ by Author. Published by Universitas Pendidikan Ganesha.

\begin{abstract}
A B S T R A K
Pandemi Covid-19 memberikan banyak pengaruh dalam dunia Pendidikan, salah satunya adalah guru kesulitan dalam mengontrol dan menjaga suasana belajar karena terbatas dalam ruang virtual, konsentrasi dari rumah dan disekolah tentu akan berbeda. Hal ini menyebabkan hasil belajar siswa menjadi rendah. Penelitian ini bertujuan untuk menganalisis atlas DP2D (Dalam Proses Pembelajaran Daring) untuk meningkatkan hasil belajar biologi di masa pandemi covid-19. Penelitian ini merupakan penelitian tindakan kelas (PTK). Subjek penelitian ini berjumlah 34 Orang siswa dengan rincian 18 Orang peserta didik Perempuan dan 16 Orang peserta didik laki-laki. Metode pengumplan data menggunakan tes melalui aplikasi quizizz. Teknik analisis data menggunakan analisis kuantitatif dan kualitatif. Hasil yang diperoleh untuk hasil belajar biologi mengalami peningkatan dari siklus I ke siklus II. Dari 30 soal objektif yang diberikan sebagai alat ukur hasil belajar diperoleh Rata-rata Accuracy nilai, yaitu dari $75,47 \%$ pada siklus I menjadi $79,09 \%$ pada siklus II. Perolehan Accuracy Tertinggi untuk siklus I yaitu $90 \%$ dan II yaitu $100 \%$. Perolehan Accuracy terendah dari $40 \%$ pada siklus I menjadi $60 \%$ pada siklus II. Sedangkan untuk persentase ketuntasan peserta didik dari $58,82 \%$ pada siklus I menjadi $85,29 \%$. Ketuntasan klasikal di siklus I belum tercapai dan baru tercapai di siklus II dengan ketentuan ketuntasan klasikal adalah 85\%. Maka, atlas DP2D (Dalam Proses Pembelajaran Daring) dapat meningkatkan hasil belajar Biologi di masa pandemi Covid-19.
\end{abstract}

\section{A B S TRACT}

The Covid-19 pandemic has had a lot of influence in the world of education, one of which is the difficulty of teachers in controlling and maintaining the learning atmosphere because they are limited in virtual spaces, concentration from home and at school will certainly be different. This causes student learning outcomes to be low. This study aims to analyze the DP2D atlas (In the Online Learning Process) to improve biology learning outcomes during the covid-19 pandemic. This research is classroom action research (CAR). The subjects of this study amounted to 34 students with details of 18 female students and 16 male students. The data collection method uses a test through the quizizz application. The data analysis technique used quantitative and qualitative analysis. The results obtained for the learning outcomes of biology have increased from cycle I to cycle II. Of the 30 objective questions given as a measuring tool for learning outcomes, the average accuracy value was obtained, namely from $75.47 \%$ in the first cycle to $79.09 \%$ in the second cycle. The Highest Accuracy Gain for the first cycle is $90 \%$ and for the second cycle is $100 \%$. The lowest Accuracy gain is from $40 \%$ in the first cycle to $60 \%$ in the second cycle. Meanwhile, the percentage of students' completeness from $58.82 \%$ in the first cycle to $85.29 \%$. Classical completeness in cycle I has not been achieved and has only been achieved in cycle II with the provisions of classical completeness is $85 \%$. So, the DP2D (In the Online Learning Process) atlas can improve Biology learning outcomes during the Covid-19 pandemic.

\section{PENDAHULUAN}

Pandemi COVID-19 yang terjadi telah membawa perubahan bagi Indonesia. Virus ini membawa dampak besar bagi seluruh sektor kehidupan (Durnalı, 2020; Guan et al., 2020; Malyana, 2020). 
Akibatnya banyak fasilitas pendidikan, pusat perbelanjaan dan lain sebagainya yang ditutup. Khususnya bidang pendidikan diterapkan berbagai kebijakan salah satunya pembelajaran online untuk menunjang pendidikan (Franchi, 2020; Pendy \& Mbagh, 2021; Purwanto, 2020). Pendidikan memiliki makna sebagai proses yangmempengaruhi peserta didik untuk mampu beradaptasi dengan lingkungannya (A. R. Setiawan, 2020; D. Setiawan, 2017). Peran pendidikan adalah meningkatkan sumber daya manusia (SDM) yang unggul dalam upaya meningkatkan kualitas pendidikan secara nasional dan internasional dalam upaya menghadapi persaingan global (N. K. Dewi et al., 2018; Ramadhani \& Fauziah, 2020). Salah satu upaya pengembangan dalam bidang pendidikan ditandai dengan penggunaan berbagai metode secara bervariasi yang sesuai dengan karakteristik materi, karakteristik peserta didik,dan fasilitas yang ada dalam pembelajaran (Br Sinulingga et al., 2019; I Ketut Nirta, 2019). Pembelajaran merupakan suatu rangkaian kegiatan yang dirancang dan dikembangkan dengan tujuan untuk membantu proses belajar melalui bantuan yang diberikan oleh guru sehingga dapat membantu peserta didik memperoleh ilmu dan pengetahuan, penguasaan kecakapan, pembentukan sikap,dan kepribadian peserta didik (Khanifah et al., 2012; Paul \& Singh, 2020).

Namun, kenyataannya pembelajaran saat pandemi covid-19 menimbulkan beberapa kendala. Selama pembelajaran daring yaitu guru kesulitan dalam mengontrol dan menjaga suasana belajar karena terbatas dalam ruang virtual, konsentrasi dan motivasi anak belajar dari rumah dan disekolah tentu akan berbeda (Muhammad Fikri, Muhammad Zaki Ananda, 2021). siswa merasa bosan terlalu lama tidak bertemu dengan guru dan teman-temannya. Tidak semua siswa memiliki fasilitas penunjang pembelajaran seperti $H P$ atau laptop, minimnya pengetahuan guru, siswa dan orang tua mengenai penggunaan teknologi, dan permasalahan lain terjadi pada proses penilaian serta peluang memperoleh pekerjaan setelah lulus pendidikan (Aji, 2020; Anugrahana, 2020; Cahyani, 2020). Orang tua yang semula hanya bertugas mencari uang untuk biaya sekolah tapi sekarang memiliki tugas tambahan mendampingi siswa belajar dirumah. Guru yang semula menjadi model di depan kelas saat mengajar, sekarang harus berkutat dengan leptop atau piranti lain dengan menyelusup dunia maya untuk mengajar, sedangkan siswa yang menjadi objek orang tua dan guru dalam proses pembelajaran menjadi objek yang dirasa paling menderita karena mendapat tekanan dari orang tua yang tiba-tiba menjadi guru, para guru disekolah dituntut dengan berbagai metode pembelajaran yang diikuti dengan berbagai macam tugas yang harus dikirim ke berbagai link google drive sampai mendapat tugas membuat video. sebagain besar siswa belum memahami pentingnya proses pembelajaran untuk mendewasakan diri bukan semata-mata mengejar nilai minimal tuntas KKM, hal itu menyebabkan mereka membuat tugas, terkadang yang penting buat malah, yang lebih parah mengabaikan seakan-akan tidak ada tuntutan tugas dari guru.

Solusi yang dapat dilaksanakan yaitu dengan menerapkan model dan media. Media yang dapat memberikan kebebasan bagi siswa untuk mengeksplorasi pengetahuan pada materi biologi. Media yang dapat digunakan yaitu media atlas. Atlas adalah salah satu media pembelajaran visual. Atlas dalam mata pelajaran biologi merupakan kumpulan gambar-gambar lengkap yang disertai dengan materi yang dikaji didalamnya (Ales et al., 2017). Selain itu, perlu menggunakan model pembelajaran yang efektif. Pembelajaran Berbasis Proyek (Project Based Learning=PjBL) adalah model pembelajaran yang menggunakan proyek/kegiatan sebagai inti pembelajaran (R. Dewi, 2020; Elisabet et al., 2019; Safitri et al., 2018). Pembelajaran berbasis proyek adalah strategi pembelajaran yang memberdayakan siswa untuk memperoleh pengetahuan dan pemahaman baru berdasar pengalamannya melalui berbagai presentasi (Fitri et al., 2018; Widarti et al., 2020). PjBL merupakan model belajar yang menggunakan masalah sebagai langkah awal dalam mengumpulkan dan mengintegrasikan pengetahuan baru berdasarkan pengalamannya dalam beraktifitas secara nyata (Sukmasari \& Rosana, 2017; Sumarni et al., 2017). Adapun langkah-langkah PjBL: 1) Penentuan pertanyaan mendasar (Start With The Essention Question), 2) Mendesain perencanaan proyek (Design a Plan For The Project), 3) Menyusun jadwal (Create a Scedule), 4) Memonitor peserta didik dan kemajuan proyek (Monitor the Students and the Progress of the Project), 5) Menguji hasil (Assess the Outcome), dan 6) Mengevaluasi Pengalaman (Evaluate the Experience) (N. P. E. Y. Pratiwi et al., 2018; Sumarni et al., 2017).

Beberapa temuan menyatakan model pjbl media atlas dapat membantu siswa lebih mudah dalam memahami materi. Melalui media atlas guru dan siswa pasti berada pada harapan peningkatan hasil belajar. Peningkatan hasil belajar dapat dilakukan dengan menerapkan model pembelajaran seperti model pembelajaran berbasis proyek (Ismail, 2018; Sari \& Angreni, 2018; Sukmasari \& Rosana, 2017) . model pjbl memberikan pegaruh terhadap kemampuan berpikir siswa (N. P. E. Y. Pratiwi et al., 2018; Sumarni et al., 2017). Penelitian terkait penggunaan model pjbl sudah banyak dilaksanakan. Namun, belum ada kajian yang menunjukkan penerapan model pjbl dengan media atlas. Model pembelajaran yang dapat merangkum semua teori yang telah disampaikan. Maka Projek based learning (PjBL) berbasis atlas untuk mengatasi proses pembelajaran daring dimasa pandemi covid-19. Tujuan penelitian ini untuk menganalisis Atlas DP2D untuk meningkatkan hasil belajar biologi di masa pandemi covid-19. 


\section{METODE}

Penelitian ini merupakan penelitian tindakan kelas (PTK) yang dilaksanakan pada semester genap Tahun pelajaran 2020/2021 di SMA Negeri 1 Semarapura, beralamat di Jalan Plamboyan No 63 Semarapura. Penelitian ini dilakukan pada bulan Pebruari sampai Juni. Tahap persiapan pada bulan Pebruari minggu pertama, tahap pelaksanaan pada bulan pebruari minggu kedua sampai bulan April minggu ketiga, penulisan laporan mulai bulan April minggu keempat sampai bulan Juni. Subjek penelitian adalah siswa kelas XI MIPA 3 yang berasal dari wilayah Kabupaten Klungkung dan sekitarnya yang berjumlah 34 orang dengan rincian 18 orang siswa perempuan dan 16 orang siswa laki-laki, sedangkan objek penelitian adalah hasil belajar biologi. Rancangan penelitian adalah suatu kesatuan, rencana terinci dan spesifik mengenai cara memperoleh, menganalisis, dan menginterpretasi data. Dalam penelitian ini digunakan prosedur penelitian dengan dasar prosedur penelitian yang diungkapkan oleh Arikunto (2010). Penelitian ini dilaksanakan dalam dua siklus pembelajaran yang tiap siklusnya terdiri dari empat tahapan yaitu: 1) perencanaan tindakan, 2) pelaksanaan tindakan, 3) observasi dan evaluasi, dan 4) refleksi. Rancangan Penelitian Tindakan Kelas pada Gambar 1.

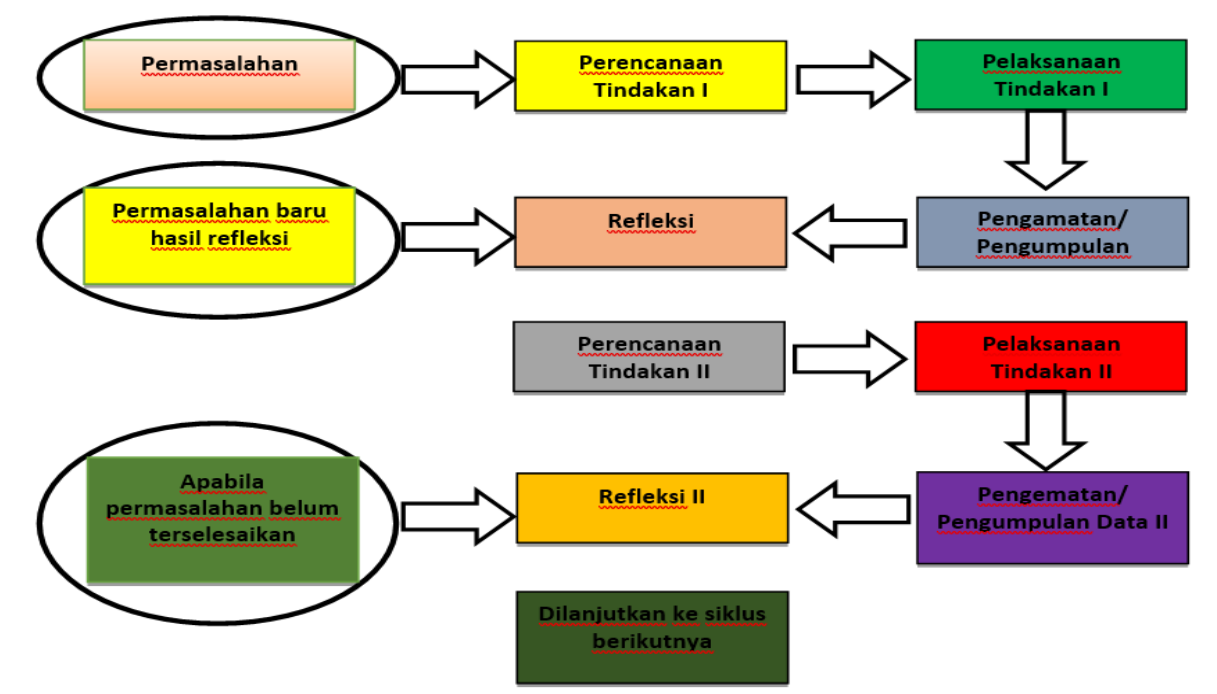

Gambar 1. Alur Penelitian Tindakan Kelas

Langkah-langkah dalam perencanaan penelitian adalah 1) mengkaji materi pokok, rencana pelaksanaan pembelajaran (RPP) dan LKS, 2) mempersiapkan dan mengkaji format-format observasi dan evaluasi yang terdiri dari post-test hasil belajar, Langkah pelaksanaan tindakan pada prinsipnya merupakan realisasi dari suatu tindakan yang sudah direncanakan. Pada siklus I, materi pokok yang dikaji adalah sistem koordinasi yang ditugaskan dalam bentuk proyek membuat atlas dengan waktu pengerjaan dua minggu, untuk pemahaman materi dilakukan dengan daring. Adapun langkah-langkah pelaksanaan tindakan dapat dilihat pada Tabel Tabel 1.

Tabel 1. Langkah-Langkah Perlakuan Dalam Penelitian

\begin{tabular}{|c|c|c|}
\hline No & Komponen Perlakuan & Tindakan \\
\hline 1 & Materi pelajaran & $\begin{array}{l}\text { Materi Untuk kompetensi dasar yang diajarkan diberikan secara } \\
\text { daring berupa link video dan link PowerPoint (PPt) yang diambil dari } \\
\text { youtub, Link materi yang diambil dari google dan juga materi sejenis } \\
\text { di bagikan di google clasroom dan di perkaya oleh siswa dengan } \\
\text { mencari di situs-situs resmi dalam bentuk PDF }\end{array}$ \\
\hline 2 & Waktu pembelajaran & Tugas membuat atlas sesuai kompetensi dasar yang dibahas \\
\hline 3 & Tes akhir & Tes hasil belajar dengan menggunakan aplikasi quizizz \\
\hline 4 & Proses Pembelajaran & $\begin{array}{l}\text { Semua informasi dalam pembelajaran daring diberikan melalui } \\
\text { aplikasi Google Clasroom dan WhatsApp sedangkan proses } \\
\text { pembelajaran dilakukan dengan Vidio conference (VICON) dengan } \\
\text { aplikasi Google meet. }\end{array}$ \\
\hline
\end{tabular}


Dalam penelitian, semua proses pembelajaran dilakukan secara daring. Pada akhir kegiatan siswa diberi test untuk mengukur hasil belajar siswa. Tahapan proses pembelajaran dapat diringkas dalam Tabel 2 .

Tabel 2. Sintak Project Based lesrning (PjBL) dengan Media Atlas Siklus I.

\begin{tabular}{|c|c|c|}
\hline No & Sintak & Kegiatan \\
\hline 1 & $\begin{array}{l}\text { Menentukan pertanyaan } \\
\text { mendasar (Start with the } \\
\text { Essential Question) }\end{array}$ & $\begin{array}{l}\text { - Diberikan beberapa gambar dan link video di YouTube } \\
\text { yang dikirim ke Google classroom dilanjutkan diskusi } \\
\text { melalui vicon dengan google meet dan WhatsApp } \\
\text { diharapkan dengan melihat gambar tersebut muncul rasa } \\
\text { ingin tau terhadap gambar dan video yg di tampilkan }\end{array}$ \\
\hline 2 & $\begin{array}{l}\text { Menyusun perencanaan proyek } \\
\text { (Design a Plan for the Project) }\end{array}$ & $\begin{array}{l}\text { - Guru memberikan LKS yang berisi panduan proyek } \\
\text { membuat atlas yang akan dikerjakan siswa }\end{array}$ \\
\hline 3 & $\begin{array}{l}\text { Menyusun jadwal (Create a } \\
\text { Schedule) }\end{array}$ & $\begin{array}{l}\text { - Guru memberikan batas waktu pengumpulan tugas } \\
\text { dengan melihat batas kewajaran pengerjaan akan tugas } \\
\text { tersebut }\end{array}$ \\
\hline 4 & $\begin{array}{l}\text { Memantau peserta didik dan } \\
\text { kemajuan proyek (Monitor the } \\
\text { Students and the Progress of the } \\
\text { Project) }\end{array}$ & $\begin{array}{l}\text { - Pemantauan kemajuan pengerjaan proyek dan membantu } \\
\text { mengatasi berbagai masalah yang di timbulkan dalam } \\
\text { kegiatan pengerjaan proyek melalui group whatsApp dan } \\
\text { Vidio conference (VICON) dengan google meet }\end{array}$ \\
\hline 5 & $\begin{array}{l}\text { Menguji hasil proyek (Assess the } \\
\text { Outcome) }\end{array}$ & $\begin{array}{l}\text { - Mengumpulkan hasil atlas ke google Drive yang disepakati } \\
\text { kemudian siswa diberi kesempatan untuk membaca } \\
\text { semua atlas hasil karya temannya kemudian didiskusikan } \\
\text { melalui Vicon dengan google meet. }\end{array}$ \\
\hline 6 & $\begin{array}{l}\text { Mengevaluasi pengalaman } \\
\text { (Evaluate the Experience) }\end{array}$ & $\begin{array}{l}\text { - Guru melakukan evaluasi dengan mengukur hasil belajar } \\
\text { siswa dengan tes objektif melalui aplikasi quizizz. }\end{array}$ \\
\hline
\end{tabular}

Selama proses diskusi melalui media whatsApp dan Video Conference berlangsung, peneliti melakukan observasi terhadap strategi pembelajaran yang diterapkan. Evaluasi dilakukan terhadap variabel-variabel yang diamati sesuai dengan objek penelitian, yaitu hasil belajar siswa, Berdasarkan observasi dan evaluasi pada siklus yang dilakukan, peneliti mengadakan refleksi untuk melihat seberapa besar keberhasilan dan kegagalan dalam penerapan metode pembelajaran yang dirancang. Refleksi dilakukan terhadap minat belajar siswa dan mencari faktor-faktor penyebab ketidak berhasilan tindakan serta mencari solusi terhadap permasalahan tersebut. Pencermatan yang dilakukan pada penerapan siklus dievaluasi dan diinterpretasi penyebabnya untuk selanjutnya digunakan sebagai acuan dalam melakukan pemantapan pada siklus selanjutnya. Sedangkan evaluasi untuk mengukur hasil belajar siswa dilakukan di setiap akhir siklus dengan menggunakan soal objektif dengan jumlah soal dan tingkat kesukaran yang diusahakan tidak berbeda.

Dalam penelitian ini dikembangkan dua perangkat pelajaran dan instrumen peneliti. Perangkat pembelajaran yang dimaksud adalah rencana pembelajaran (RPP) Project Based Learning (PjBL) dengan media atlas. Instrumen penelitian yang dimaksud adalah test objektif yang penggunaaannya menggunakan aplikasi quizizz. Rencana pelaksanaan pembelajaran yang dikembangkan pada penelitian ini merupakan perwujudan dari pembelajaran yang digunakan dalam penelitian, yaitu RPP PjBL dengan media atlas. Rencana pembelajaran yang dikembangkan mengacu pada kurikulum 2013 untuk mata pelajaran biologi. Langkah-langkah yang dilakukan dalam pengembangan RPP satu lembar adalah (1) menentukan tujuan pembelajaran, (2) merancang kegiatan pembelajaran PjBL dengan media atlas, (3) menentukan penilaian, (4) menyertakan lampiran yang diperlukan. Lembar kerja peserta didik (LKPD) sangat penting dalam sebuah RPP karena sebagai fasilitas pendukung pembelajaran. LKPD yang dikembangkan pada penelitian ini digunakan untuk mengaplikasikan proses pembelajaran yang akan diberikan pada kegiatan daring. Sedangkan Instrumen penelitian merupakan alat bantu bagi peneliti dalam mengumpulkan data. Kualitas instrumen akan menentukan kualitas data yang terkumpulkan (Arikunto, 2010). Instrumen yang digunakan dalam penelitan ini untuk mengukur hasil belajar dalam pelajaran biologi digunakan tes objektif, dengan kriteria penskoran untuk jawaban benar mendapatkan skor 1 dan untuk jawaban salah mendapatkan skor 0 .

Secara umum data yang didapat dalam penelitian dapat dikelasifikasikan menjadi dua kelompok data, yaitu data kualitatif dan data kualitatif yang dinyatakan dalam kata-kata atau simbol. Data kuantitatif yaitu data yang dapat menggambarkan kenyataan atau fakta sesuai data yang diperoleh dengan tujuan untuk mengetahui respon aktivitas siswa selama proses pembelajaran berlangsung. Dalam menganalisis 
data kuantitatif akan berkaitan dengan data kuantitatif, sebab data kuantitatif menyertai dan melengkapi gambaran dari data kuantitatif (Arikunto, 2010). Analaisis data merupakan cara yang digunakan dalam pengelolaan data dan hal tersebut berhubungan erat dengan perumusan masalah yang telah diajukan sehingga dapat digunakan untuk menarik kesimpulan. Perhitungan analisis dilakukan dengan menggunakan statistik sederhana Persentase ketuntasan Dalam penelitian ini diusulkan tingkat keberhasilan per siklus yaitu mencapai nilai ketuntasan minimal individual yaitu 75 sesuai ketuntasan KKM SMAN 1 Semarapura, sedangkan menurut depdiknas (2006) bahwa pembelajaran dikatakan tuntas apabila secara klasikal siswa mendapat nilai minimal KKM mencapai 85\%. maka untuk penelitian ini ditetapkan ketuntasan klasikal adalah 85\%.

\section{HASIL DAN PEMBAHASAN}

\section{Hasil}

Hasil tindakan siklus I hasil belajar biologi diperoleh dengan melakukan tes dengan menggunakan aplikasi quizizz. Berdasarkan hasil observasi siklus I, didapatkan data tentang hasil belajar biologi yang dapat dilihat pada Tabel 3.

Tabel 3. Data Hasil Belajar Biologi Peserta didik Siklus I

\begin{tabular}{cc}
\hline Deskripsi Statistik & Hasil Belajar Biologi \\
\hline Jumlah Siswa (Orang) & 34 \\
Jumlah Soal Objektif & 30 \\
Jumlah Accuracy & 2566 \\
Rata-rata Accuracy (\%) & 75,47 \\
Accuracy Tertinggi (\%) & 90 \\
Accuracy Terendah (\%) & 40 \\
Siswa yang Accuracy $<75 \%$ & 14 \\
Siswa yang Accuracy $\geq 75 \%$ & 20 \\
Ketuntasan Klasikal (\%) & 58,82 \\
\hline
\end{tabular}

Berdasarkan Tabel 03 dapat diketahui beberapa informasi yaitu perolehan hasil belajar biologi untuk Accuracy terendah yaitu $40 \%$ dan Accuracy tertinggi 90\%, dengan nilai rata-rata Accuracy peserta didik sebesar 75,47\% dengan kategori cukup, jumlah peserta didik yang mencapai Accuracy $<75$ sebanyak 14 orang $(41,18 \%)$, sedangkan peserta didik yang mencapai Accuracy $\geq 75$ sebanyak 20 orang (58,82\%) dengan ketuntasan klasikal 58,82\%. Hasil ini menunjukkan bahwa ketuntasan secara klasikal belum tercapai, yaitu minimal sebesar $85 \%$. Perolehan hasil ini, tidak terlepas dari penerapan metode pembelajaran yang relatif baru, serta tuntutan hasil belajar yang lebih tinggi, karena menyangkut pemahaman secara komprehensif. Oleh karena itu, diperlukan strategi yang lebih efektif dan efisien dalam rangka meningkatkan hasil belajar biologi. Berdasarkan hasil obervasi siklus I dilakukan refleksi bahwa ternyata Penerapan PjBL dengan media atlas pada mata pelajaran biologi dengan materi sistem koordinasi, belum berlangsung dengan baik yang mengakibatkan ketuntasan klasikal belum dapat tercapai, hal ini disebabkan oleh peserta didik belum terbiasa dengan proyek membuat atlas dalam pelajaran biologi, sehingga siswa masih banyak memerlukan bimbingan. Peserta didik belum maksimal dalam mengeksplorasi pemahaman terhadap materi yang dibaca sehingga belum maksimal dalam menuangkan ke atlas. Sebelum diadakan diskusi, peserta didik diberikan kesempatan membaca atlas hasil karya temannya yang sudah ditentukan pembagiannya, sehingga mengakibatkan timbulnya pariasi pemahaman akan materi tergantung kedalaman materi yang tersirat dalam atlas yang dibaca terkecuali untuk siswa yang telah membuat atlas lebih lengkap dari atlas yang ditugaskan dibaca.

Berdasarkan hasil refleksi siklus I dilakukan beberapa penyempurnaan di siklus II,yaitu lebih mengarahkan siswa sehingga siswa lebih bebas menuangkan kreatifitasnya dalam membuat atlas dalam pelajaran biologi. Siswa di berikan kesempatan membaca atlas hasil karya seluruh temannya dengan membagikan link google drive tempat pengumpulan tugas, selain atlas yang memang ditugaskan untuk dibaca. Sehingga diharafkan ada persamaan pemahaman untuk materi yang dibahas. Untuk meyakini bahwa semua siswa telah membaca seluruh atlas yang dihasilkan sesluruh siswa, maka saat diskusi selain diadakan presentasi sesuai atlas yang dibaca juga diadakan pengacakan presentasi. Hasil tindakan siklus II, meliputi hasil belajar biologi. Berdasarkan hasil tes diakhir siklus didapatkan data tentang hasil belajar biologi yang dapat dilihat pada Tabel 4 . 
Tabel 4. Data Hasil Belajar Biologi Peserta didik Siklus II.

\begin{tabular}{cc}
\hline Deskripsi Statistik & Hasil Belajar Biologi \\
\hline Jumlah Siswa (Orang) & 34 \\
Jumlah Soal Objektif & 30 \\
Jumlah Accuracy & 2689 \\
Rata-rata Accuracy (\%) & 79,09 \\
Accuracy Tertinggi (\%) & 100 \\
Accuracy terendah (\%) & 60 \\
Siswa yang Accuracy $<75 \%$ & 5 \\
Siswa yang Accuracy $\geq 75 \%$ & 29 \\
Ketuntasan Klasikal (\%) & 85,29 \\
\hline
\end{tabular}

Berdasarkan Tabel 04 dapat diketahui beberapa informasi yaitu perolehan hasil belajar biologi untuk Accuracy terendah yaitu 60\% dan Accuracy tertinggi 100\%, dengan nilai rata-rata Accuracy peserta didik sebesar 79,09\% dengan kategori Cukup, jumlah peserta didik yang mencapai Accuracy $<75$ sebanyak 5 orang (14,71\%), sedangkan peserta didik yang mencapai Accuracy $\geq 75$ sebanyak 29 orang $(85,29 \%)$ dengan ketuntasan klasikal 85,29\%. Hasil ini menunjukkan bahwa ketuntasan secara klasikal sudah tercapai, yaitu lebih dari 85\%. Perolehan hasil ini terjadi karena siswa mulai terbisa dengan metode pembelajaran yang di terapkan. Hasil belajar peserta didik antara siklus I dan siklus II memperlihatkan peningkatan yang signifikan, itu bisa dilihat pada Tabel 05 .

Tabel 5. Perbandingan hasil belajar biologi peserta didik siklus I dan siklus II.

\begin{tabular}{ccc}
\hline KETERANGAN & Siklus I & Siklus II \\
\hline Jumlah Siswa (Orang) & 34 & 34 \\
Jumlah Soal Objektif & 30 & 30 \\
Jumlah Accuracy (\%) & 2566 & 2689 \\
Rata-rata Accuracy (\%) & $75,47 \%$ & $79,09 \%$ \\
Accuracy Tertinggi (\%) & $90 \%$ & $100 \%$ \\
Accuracy terendah (\%) & $40 \%$ & $60 \%$ \\
Siswa yang Accuracy <75\% & $14(41,18 \%)$ & $5(14,71 \%)$ \\
Siswa yang Accuracy $\geq 75 \%$ & $20(58,82 \%)$ & $29(85,29 \%)$ \\
Ketuntasan klasikal (\%) & $58,82 \%$ & $85,29 \%$ \\
\hline
\end{tabular}

\section{Pembahasan}

Dimasa pandemi Covid 19 yang berlangsung lebih dari 1 tahun tepatnya sejak tanggal 16 Maret 2020 kebijakan pemerintah bahwa proses pembelajaran dilaksanakan dengan proses daring. Bagaimana mengajar daring dan bagaimana belajar daring sama-sama menjadi istilah yang membingungkan baik untuk guru dan juga bagi siswa. Berbagai inovasi dilakukan oleh guru dalam melaksanakan proses pembelajaran daring yang membuat siswa untuk beradaptasi dengan berbagai metode pembelajaran baru yang diterapkan guru. Melalui penerapan model PjBL media atlas dapat meningkatkan hasil belajar biologi. Hal ini dikarenakan proses pembelajaran sama seperti game, membuat siswa kecanduan terhadap game dan tidak kenal waktu untuk dikerjakan. Permainan yang menuntut inovasi untuk memperbesar wilayak dengan membangun apa saja (Amania et al., 2021; Gokbulut, 2020; Pratama et al., 2021). Proses pembelajaran projek based learning dengan menggunakan media atlas dalam pembelajaran biologi, siswa diberikan tugas mengerjakan atlas dengan materi sistem koordinasi untuk siklus I dan sistem reproduksi untuk siklus II. Dalam proses pengerjaan atlas siswa berikan kebebasan untuk berinovasi dalm membuat atlas. Baik menggunakan gambar, diwarnai walau sampai pool caller, jenis huruf bebas dipilih sampai menambahkan hiasan untuk menambah artistic pada atlas tetap diberikan tapi secara konsep keilmuan tetap dalam bingkai kompetensi dasar pengetahuan dan keterampilan yang dituntut oleh kurikulum.

Keberhasilan penerapan Projek Based Learning (PjBL) berbasisi atlas dapat meningkatkan hasil belajar siswa di kelas XI MIPA 3 di SMAN 1 Semarapura terbukti karena dalam proses pembelajaran. Kebebasan berinovasi dalam proses pengerjaan atlas berikan karena proses pembelajaran yang dilakukan dengan menyenangkan akan mendapatkan hasil pemahaman siswa akan semakin baik. Belajar menyenangkan akan memudahkan timbulnya hubungan yang dinamis dalam lingkungan kelas, interaksi yang timbul pada siswa merupakan kerangka untuk belajar (Fauzia \& Kelana, 2021; I. A. Pratiwi et al., 2018; Saputro \& Rayahu, 2020). Ada tiga tipe modalitas belajar manusia yaitu tipe visual (belajar dengan cara melihat), auditorial (belajar dengan cara mendengar), dan kinestesial (belajar dengan cara bergerak, bekerja dan menyentuh) (M. S. A. Dewi \& Lestari, 2020; N. P. E. Y. Pratiwi et al., 2018). Apabila seseorang 
mampu mengenali tipe belajar dan melakukan pembelajaran yang sesuai maka belajar akan terasa sangat menyenangkan dan memberikan hasil yang optimal (Ismail, 2018). Tetapi dengan menggunakan PjBL dengan media atlas akan dapat mengakumulasi semua tipe modalitas belajar manusia, baik tipe visual, auditorial, dan kinestesial. Keberhasilan penerapan PjBL dengan media atlas dapat meningkatkan hasil belajar siswa di kelas XI MIPA 3 di SMAN 1 Semarapura terbukti dengan hasil siklus I dan siklus II yang mengalami peningkatan. Keberhasilan temuan ini diperkuat dengan penelitian sebelumnya yang menyatakan pengembangan media pembelajaran biologi atlas invertebrata untuk siswa kelas X SMA layak digunakan oleh siswa kelas X (Ales et al., 2017). Melalui media atlas guru dan siswa pasti berada pada harapan peningkatan hasil belajar. Peningkatan hasil belajar dapat dilakukan dengan menerapkan model pembelajaran seperti model pembelajaran berbasis proyek (Ismail, 2018; Sari \& Angreni, 2018; Sukmasari \& Rosana, 2017). Model pjbl memberikan pegaruh terhadap kemampuan berpikir siswa (N. P. E. Y. Pratiwi et al., 2018; Sumarni et al., 2017). Implikasi penelitian ini diharapkan dapat meningkatkan hasil belajar biologi melalui penerapan model PjBL berbasis media atlas.

\section{SIMPULAN}

Model PJBL media atlas dapat meningkatkan hasil belajar di masa pandemic Covid-19. Dalam usaha memperoleh hasil belajar biologi yang optimal dalam masa pandemic Covid-19 hendaknya guru lebih inovatif dalam mendisain proses dan media pembelajaran. Sehingga tidak menimbulkan kebosanan dan kejenuhan pada siswa saat belajar daring dan lebih mudah bagi siswa untuk memahami materi dalam proses pembelajaran mandiri. Selain itu, siswa dapat belajar untuk meningkatkan kualitas intelektual dan kreativitas serta siap dengan perubahan proses pembelajaran yang terkadang bisa berubah. Dengan kemampuan intelektual yang dikuasai maka peserta didik nantinya akan bisa bersaing di dunia kerja. Sedangkan dengan kreativitas yang terlatih maka peserta didik nantinya akan bisa menunjukan prestasi kerja dengan mampu melaksanakan semua tanggung jawab yang diberikan dengan baik.

\section{DAFTAR RUJUKAN}

Aji, R. H. S. (2020). Dampak Covid-19 pada Pendidikan di Indonesia: Sekolah, Keterampilan, dan Proses Pembelajaran? Dampak Covid-19 pada Pendidikan di Indonesia: Sekolah, Keterampilan, dan Proses Pembelajaran. Jurnal Sosial \& Budaya Syar-I, 5(1), 395-402. https://doi.org/10.15408/sjsbs.v7i5.15314.

Ales, L., Bellofatto, A. A., \& Wang, J. J. (2017). Taxing Atlas: Executive Compensation, Firm Size, and Their Impact on Optimal Top Income Tax Rates. Review of Economic Dynamics, 26, 62-90. https://doi.org/10.1016/j.red.2017.02.007.

Amania, M., Nugrahanta, G. A., \& Irine Kurniastuti. (2021). Pengembangan Modul Permainan Tradisional sebagai Upaya Mengembangkan Karakter Adil pada Anak Usia 9-12 Tahun. Elementary School, 8(2), 237-251. https://doi.org/10.31316/esjurnal.v8i2.1230.

Anugrahana, A. (2020). Hambatan, Solusi dan Harapan: Pembelajaran Daring Selama Masa Pandemi Covid-19 Oleh Guru Sekolah Dasar. Jurnal Pendidikan Dan Kebudayaan, 10(3), 282-289. https://doi.org/10.24246/j.js.2020.v10.i3.p282-289.

Br Sinulingga, S. H., Jaria, J., \& Barus, E. (2019). Development of Animation-Based Teaching Material on Explanation Text on XI Grade Students at MAN 2 Aceh Tenggara. AKSIS: Jurnal Pendidikan Bahasa Dan Sastra Indonesia, 3(2), 257-266. https://doi.org/10.21009/AKSIS.030203.

Cahyani, A. dkk. (2020). Motivasi Belajar Siswa SMA pada Pembelajaran Daring di Masa Pandemi Covid19. Jurnal Pendidikan Islam, 3(1), 123-14. https://doi.org/10.37542/iq.v3i01.57.

Dewi, M. S. A., \& Lestari, N. A. P. (2020). E-Modul Interaktif Berbasis Proyek Terhadap Hasil Belajar Siswa. Jurnal Ilmiah Pendidikan Dan Pembelajaran, 4(3), 433-441. https://doi.org/10.23887/jipp.v4i3.28035.

Dewi, N. K., Tirtayani, L. A., \& Kristiantari, R. (2018). Pengaruh Metode Bermain Peran Terhadap Kemampuan Sosial Anak Kelompok B di Paud Gugus Anggrek, Kuta Utara. Jurnal Pendidikan Anak Usia Dini Universitas Pendidikan Ganesha, 6(1), 43-53. https://doi.org/10.23887/paud.v6i1.15090.

Dewi, R. (2020). Penerapan Model Pembelajaran Project Based Learning (PJBL) untuk Meningkatakan Aktivitas dan Hasil Belajar Siswa. Cakrawala Pedagogik, 4(1), 112-120. https://doi.org/10.51499/cp.v4i1.147.

Durnal, M. (2020). The effect of self-directed learning on the relationship between self-leadership and online learning among university students in Turkey. Tuning Journal for Higher Education, 8(1), 129-165. https://doi.org/10.18543/TJHE. 
Elisabet, E., Relmasira, S. C., \& Hardini, A. T. A. (2019). Meningkatkan Motivasi dan Hasil Belajar IPA dengan Menggunakan Model Pembelajaran Project Based Learning (PjBL). Journal of Education Action Research, 3(3), 285. https://doi.org/10.23887/jear.v3i3.19451.

Fauzia, N. L. U., \& Kelana, J. B. (2021). Natural Science Problem Solving in Elementary School Students Using the Project Based Learning (PjBL) Model. Jurnal Ilmiah Sekolah Dasar, 4(4), 596-603. https://doi.org/10.23887/jisd.v4i4.28377.

Fitri, H., Dasna, I. W., \& Suharjo, S. (2018). Pengaruh Model Project Based Learning (PjBL) Terhadap Kemampuan Berpikir Tingkat Tinggi Ditinjau dari Motivasi Berprestasi Siswa Kelas IV Sekolah Dasar. Briliant: Jurnal Riset Dan Konseptual, 3(2), 201. https: //doi.org/10.28926/briliant.v3i2.187.

Franchi, T. (2020). The Impact of the Covid-19 Pandemic on Current Anatomy Education and Future Careers: A Student's Perspective. Anatomical Sciences Education, 13(3), 312-315. https://doi.org/10.1002/ase.1966.

Gokbulut, B. (2020). The Effect of Mentimeter and Kahoot Applications on University Students' E-learning. World Journal on Educational Technology: Current Issues, 12(2), 107-116. https: //doi.org/10.18844/wjet.v12i2.4814.

Guan, W., Ni, Z., Hu, Y., Liang, W., Ou, C., He, J., Liu, L., Shan, H., Lei, C., Hui, D. S. C., Du, B., Li, L., Zeng, G., Yuen, K.-Y., Chen, R., Tang, C., Wang, T., Chen, P., Xiang, J., \& Zhong, N. (2020). Clinical Characteristics of Coronavirus Disease 2019 in China. New England Journal of Medicine, 382(18), 1708-1720. https://doi.org/10.1056/NEJMoa2002032.

I Ketut Nirta. (2019). Upaya Meningkatkan Aktivitas dan Hasil Belajar Peserta Didik Kelas IV SD Negeri 14 Cakranegara Melalui Penerapan Pendekatan Cooperative Learning Tipe Jigsaw. Jurnal Paedagogy, 6(1), 8-13. https://doi.org/10.33394/jp.v6i1.2524.

Ismail, R. (2018). Perbandingan Keefektifan Pembelajaran Berbasis Proyek Dan Pembelajaran Berbasis Masalah Ditinjau Dari Ketercapaian Tujuan Pembelajaran. Pythagoras: Jurnal Pendidikan Matematika, 13(2), 181-188. https://doi.org/10.21831/pg.v13i2.23595.

Khanifah, S., Pukan, K. K., \& Sukaesih, S. (2012). Pemanfaatan Lingkungan Sekolah Sebagai Sumber Belajar Untuk Meningkatkan Hasil Belajar Siswa. Journal of Biology Education, 1(1), 66-73. https://doi.org/10.15294/jbe.v1i1.379.

Malyana, A. (2020). Pelaksanaan Pembelajaran Daring Dan Luring Dengan Metode Bimbingan Berkelanjutan Pada Guru Sekolah Dasar Di Teluk Betung Utara Bandar Lampung. Pedagogia: Jurnal Ilmiah Pendidikan Dasar Indonesia, 2(1), 67-76. https://doi.org/10.52217/pedagogia.v2i1.640.

Muhammad Fikri, Muhammad Zaki Ananda, N. F. (2021). Kendala Dalam Pembelajaran Jarak Jauh di Masa Pandemi Covid-19: Sebuah Kajian Kritis. Jurnal Education and Development Institut Pendidikan Tapanuli Selatan, 9(1), 145-148. https://doi.org/10.37081/ed.v9i1.2290.

Paul, R., \& Singh, A. (2020). Does early childhood adversities affect physical, cognitive and language development in indian children? Evidence from a panel study. SSM - Population Health, 12(August), 100693. https://doi.org/10.1016/j.ssmph.2020.100693.

Pendy, A., \& Mbagh, H. M. (2021). Model Pembelajaran Numbered Head Together (NHT) pada Materi Pokok Relasi dan Fungsi. Jurnal Basicedu, 5(4), 2156-2163. https://doi.org/10.31004/basicedu.v5i1.542.

Pratama, H., Maduretno, T. W., \& Yusro, A. C. (2021). Online Learning Solution: Ice Breaking Application to Increase Student Motivation. Journal of Educational Science and Technology (EST), 7(1), 117-125. https://doi.org/10.26858/est.v7i1.19289.

Pratiwi, I. A., Ardianti, S. D., \& Kanzunnudin, M. (2018). Peningkatan Kemampuan Kerjasama Melalui Model Project Based Learning (Pjbl) Berbantuan Metode Edutainment Pada Mata Pelajaran Ilmu Pengetahuan Sosial. Refleksi Edukatika: Jurnal Ilmiah Kependidikan, 8(2). https://doi.org/10.24176/re.v8i2.2357.

Pratiwi, N. P. E. Y., Pudjawan, K., \& Sukmana, A. I. W. I. Y. (2018). Pengembangan Multimedia Pembelajaran Interaktif Berbasis Proyek pada Mata Peajaran Bahasa Indonesia pada siswa Kelas V. Edutech Universitas Pendidikan Ganesha, 6, 123-133. https://doi.org/10.23887/jeu.v6i1.20277.

Purwanto, A. (2020). Studi eksplorasi Dampak WFH Terhadap Kinerja Guru. Journal of Education, Psychology and Counseling, 2(1), 92-100. https://ummaspul.ejournal.id/Edupsycouns/article/view/397.

Ramadhani, P. R., \& Fauziah, P. Y. (2020). Hubungan Sebaya dan Permainan Tradisional pada Keterampilan Sosial dan Emosional Anak Usia Dini. Jurnal Obsesi : Jurnal Pendidikan Anak Usia Dini, 4(2), 1011. https://doi.org/10.31004/obsesi.v4i2.502.

Safitri, N. L., Zubaidah, S., \& Kuswantoro, H. (2018). Pengembangan LKS Project Based Learning Berbasis 
Penelitian Perlakuan Perbedaan Dosis Fosfat pada Genotipe Kedelai. Jurnal Pendidikan: Teori, Penelitian, Dan Pengembangan, 3(4), 518-523. https://doi.org/10.17977/jptpp.v3i4.10813.

Saputro, O. A., \& Rayahu, T. S. (2020). Perbedaan Pengaruh Penerapan Model Pembelajaran Project Based Learning ( Pjbl) Dan Problem Based Learning ( Pbl ) Berbantuan Media Monopoli. Jurnal Imiah Pendidikan Dan Pembelajaran, 4(1), 185-193. https://doi.org/10.23887/jipp.v4i1.24719.

Sari, R. T., \& Angreni, S. (2018). Penerapan Model Pembelajaran Project Based Learning (PjBL) Upaya Peningkatan Kreativitas Mahasiswa. Jurnal VARIDIKA, 30(1), 79-83. https://doi.org/10.23917/varidika.v30i1.6548.

Setiawan, A. R. (2020). Peningkatan Literasi Saintifik Melalui Pembelajaran Biologi Menggunakan Pendekatan Saintifik. Journal of Biology Education, 2(1), 1. https://doi.org/10.21043/jobe.v2i1.5278.

Setiawan, D. (2017). Pendekatan Saintifik dan Penilaian Auntentik untuk Meningkatkan Mutu Pembelajaran Pendidikan Agama Islam. AL-ASASIYYA: Journal of Basic Education, 1(2). https://doi.org/10.24269/ajbe.v1i2.683.

Sukmasari, V. P., \& Rosana, D. (2017). Pengembangan penilaian proyek pembelajaran IPA berbasis discovery learning untuk mengukur keterampilan pemecahan masalah. Jurnal Inovasi Pendidikan IPA, 3(1), 101. https://doi.org/10.21831/jipi.v3i1.10468.

Sumarni, W., Wijayati, N., \& Supanti, S. (2017). Analisis Kemampuan Kognitif Dan Berpikir Kreatif Siswa Melalui Pembelajaran Berbasis Proyek Berpendekatan Stem. JUrnal Pembelajaran Kimia, 4(1), 1830. https://doi.org/10.17977/um026v4i12019p018.

Widarti, H. R., Rokhim, D. A., \& Syafruddin, A. B. (2020). The Development Of Electrolysis Cell Teaching Material Based On Stem-Pjbl Approach Assisted By Learning Video: A Need Analysis. Jurnal Pendidikan IPA Indonesia, 9(3), 309-318. https://doi.org/10.15294/jpii.v9i3.25199. 